\title{
ANALISIS HASIL BALAJAR MATEMATIKA SISWA PADA METERI MATRIKS MELALUI PEMBELAJARAN BERBASIS E- LEARNING
}

\author{
Abdul Wahab Abdullah ${ }^{1}$, Dewi Rahmawaty Isa $^{2}$, Nur Fajriani Podungge ${ }^{3}$ \\ 1,2,3 Jurusan Matematika, Universitas Negeri Gorontalo, Bone Bolango 96119, Indonesia \\ *Penulis Korespondensi. Email: nurfajrianipodungge@gmail.com
}

\begin{abstract}
Abstrak
Penelitian ini bertujuan untuk mendeskripsikan hasil belajar matematika siswa pada materi matriks melalui pembelajaran berbasis e-learning. Penelitian ini dilaksanakan di SMK Negeri 2 Limboto dengan metode deskritif yang melibatkan 21 orang siswa sebagai sampel penelitian yang dipilih dengan teknik purposive sampling. Pengumpulan data diperoleh dari hasil tes belajar matematika dengan melibatkan beberapa indikator yaitu: (1) pemahaman, (2) penerapan, (3) analisis, (4) sintesis, dan (5) evaluasi. Hasil penelitian menunjukan bahwa hasil belajar matematika siswa melalui pembelajaran berbasis e-learning berada dalam kategori kurang, yang ditunujukan dengan presentase skor yang dicapai oleh siswa adalah sebesar $69 \%$.
\end{abstract}

Kata Kunci: Hasil Belajar; Matriks; E-learning

Abstract

This study aims to describe students' mathematics learning outcomes in matrix material through e-learning based learning. This research was conducted at SMK Negeri 2 Limboto with a descriptive method involving 21 students as the research sample selected by purposive sampling technique. Data collection was obtained from the results of mathematics learning tests involving several indicators, namely: (1) understanding, (2) application, (3) analysis, (4) synthesis, and (5) evaluation. The results showed that students' mathematics learning results through e-learningbased learning were in the poor category, which was indicated by the percentage of scores achieved by students of $69 \%$.

Keywords: Learning Outcomes; Matriks; E-Learning

\section{Pendahuluan}

Adanya dampak dari penyebaran virus covid 19 diseluruh dunia termasuk juga indonesia menyebabkan pemerintah mengeluarkan aturan physical distancing, dimana semua kegiatan yang melibatkan banyak orang dalam suatu tempat dihentikan sementara. Kementrian pendidikan mengeluarkan surat edaran No,4 tentang pelaksanaan pendidikan yang dimana menghimbau kegiatan pembelajaran disekolah-sekolah dihentikan untuk sementara karena termasuk kegiatan yang melibatkan banyak orang [1]. Hal ini membuat peserta didik yang dituntut untuk belajar dari rumah menggunakan internet, guru memberikan materi lewat internet lalu diakses oleh peserta didik. Pembelajaran yang awalnya bersifat konvensional kini dialihkan dalam pembelajaran daring.

Dengan diterapkannya pembelajaran daring (online) secara mendadak, hal ini menimbulkan beberapa masalah yang dihadapi guru dan peserta didik, terlebih lagi jika pembelajaran online sebelumnya belum pernah digunakan oleh guru dalam proses pembelajaran di sekolah. Salah satu pelajaran yang akan mengalami beberapa masalah adalah pelajaran matematika, karena masih banyak peserta didik yang mengganggap bahwa pelajaran matematika itu sangat sulit dan membosankan. Apalagi jika pembelajaran matematika yang dilakukan secara daring, akan ada 
kemungkinan beberapa peserta didik tidak paham dengan penjelasan guru dalam pembelajaran. Pembelajaran daring menjadi salah satu alternatif yang bisa digunakan dalam proses pembelajaran saat ini. Pembelajaran online secara efektif untuk melaksanakna pembelajaran meskipun pendidik dan peserta didik berada di tempat yang berbeda. Seperti penelitian yang dilakukan oleh Sadikin dan Hamidah [2] yang menunjukkan bahwa pembelajaran daring memiliki fleksibilitas dalam pelaksanaannya dan mampu mendorong munculnya kemandirian belajar dan motivasi untuk lebih aktif dalam belajar. Walaupun demikian, karena situasi dan kondisi saat ini yang tidak memungkinkan untuk belajar di sekolah, maka pembelajaran daring menjadi alternatif yang bisa digunakan dalam pembelajaran [3]. Apalagi sekarang ini banyak materi-materi yang dapat diakses oleh peserta didik melalui internet, misalnya video pembelajaran yang bisa diakses melalui youtube ataupun beberapa aplikasi pembelajaran yang sudah ada saat ini, yang dapat memberikan kemudahan dalam memberikan transfer informasi pada berbagai situasi dan kondisi [4]. Hal ini menjadi tantangan terbesar bagi semua pihak terutama guru agar bisa menyampaikan materi matematika secara kreatif sehingga peserta didik tertarik dengan materi yang akan dipelajari dan memahami materi tersebut.

Perkembangan IPTEK telah membawa perubahn pesat dalam aspek kehidupan manusia. Salah satu bidang yang mendapat dampak cukup berarti adalah bidang pendidikan. Salah satunya dalam pembelajaran adalah media e-learning [5]. E-learning adalah teknologi informasi dan komunikasi mengaktifkan siswa untuk belajar kapanpun dan dimanapun. E-learning juga merupakan suatu jenis belajar mengajar yang memungkinkan tersampainya bahan ajar ke siswa dengan menggnakan media internet atau jaringan komputer lainnya. E-learning meiliki kemampuan untuk berbagi materi dalam berbagai bentuk format seperti video, powerpoint, word document, dan Pdf. Selain itu kita juga dapat berkomunikasi dengan guru yang memberikan materi via chat, message, video call dan juga terdapat tempat diskusi seperti forum-forum dimana kita dapat bertukar pendapat [6].

Pembelajaran berbasis e-learning masi menjadi solusi untuk pembelajaran matemtaika dimasa pandemik saat ini. Terdapat beberapa media e-learning yang dapat digunakan untuk proses pembelajaran di SMK khususnya SMK Negeri 2 Limboto. Media yang digunakan adalah zoom, whatsapp dan google classroom. Namun, belum dapat kita ketahui bagaimana penggunaan media $e$ learning sebagai solusi pembelajaran daring. Hal inilah yang perlu diketahui sejauh mana dampak penggunaan media e-learning dalam pembelajaran matematika di masa pandemi. Adanya $e$ learning mampu membuat penyampaian informasi belajar menjadi lebih mudah baik bagi guru dan peserta didik. seperti yang ditemukan oleh Nakayama, dkk [7] bahwa dari semua literatur dalam $e$ learning mengindikasikan bahwa tidak semua peserta didik akan sukses dalam pembelajaran online, ini dikarenakan faktor lingkungan belajar dan karakteristik peserta didik.

Media pembelajaran pada dasarnya telah banyak dikembangkan seperti pada pengembangan media berbasis ICT [8], dan juga pengembangan media berupa modul dan video pembelajaran [9]. Dengan adanya kebijakan pembelajaran online maka penelitian merujuk pada pembahasan yang berkaitan dengan pembelajaran online dengan melibatkan e-learning, seperti yang ditemukan pada [10] pembelajaran e-learning dijadikan sebagai alat bantu pada pembelajaran disekolah dan dimanfaatkan untuk meningkatkan aktifitas belajar siswa dalam pembelajaran online. E-learning mampu meningkatkan minat peserta didik yang mempelajari matematika dimana pembelajaran tidak berfokus pada guru dan juga ruang kelas berbeda halnya dengan pembelajaran yang sebelumnya monoton [11]. Penggunaa media e-learning membuat peserta didik sangat antusias dan memberikan pengalaman baru seperti yang dikemukakan pada [12][13] bahwa e-learning bisa membuat peserta didik mengakses bahan ajar atau tugas tanpa dibatasi oleh waktu. Beberapa hasil penelitian menunjukkan bahwa hasil belajar matematika dengan menggunakan media e-learning dapat dikatakan baik [14][15]. Namun penelitian tersebut dilakukan sebelum terjadinya pandemi covid-19. Hal ini tentu saja berbeda dengan apa yang kami ungkapkan dalam artikel ini. 
Oleh karena itu dalam artikel ini dilakukan analisis hasil belajar matematika siswa melalui pembelajaran berbasis e-learning, peneliti merasa perlu melakukan penelitian untuk mengetahui keberhasilan pencapaian tujuan pembelajaran matematika berbasis e-learning dengan melihat hasil belajar peserta didik, hasil belajar digunakan sebagai acuan bagi guru untuk melihat sejauh mana peserta didik memahami materi setelah mengikuti proses pembelajaran. Sehingga dapat menjadi evaluasi bagi guru untuk menyampaikan materi dengan variasi lain dalam pembelajaran berbasis $e$ learning, agar peserta didik bisa memahami materi yang dipelajari.

\section{Metode Penelitian}

Metode penelitian berisi penguraian langkah-langkah penyelesaian masalah. Uraikan dengan jelas Penelitian ini menggunakan metode penelitian deskriptif untuk mendeskripsikan hasil belajar matematika siswa pada materi matriks melalui pembelajaran berbasis e-learning. Penelitian ini melibatkan 21 orang siswa sebagai sampel penelitian yang ditentukan menggunakan teknik purposive sampling. Data yang digunakan adalah data hasil belajar yang diperoleh melalui tes essay. Data diperoleh dengan cara memberikan instrumen tes yang berbentuk tes essay pada materi matriks. Data yang diperoleh dianalisis menggunakan analisis persentase. Untuk mengetahui persentase hasil belajar digunakan rumus berikut:

$$
\text { Presentase }=\frac{\text { skor yang diperoleh }}{\text { skor maksimum }} \times 100 \%
$$

Untuk mengetahui hasil belajar masing-masing peserta didik disesuaikan dengan kategori yang tercantum dalam panduan penilaian oleh pendidik dan satuan pendidikan. Kategori hasil belajar siswa mengacu pada Tabel 1 .

Tabel 1. Kategori Hasil Belajar Siswa Berdasarkan Kriteria Penilaian

\begin{tabular}{cc}
\hline Presentase $\%$ & Kategori \\
\hline $93-100$ & Sangat Baik \\
$84-92$ & Baik \\
$78-83$ & Cukup \\
$<75$ & Kurang \\
\hline
\end{tabular}

\section{Hasil dan Pembahasan}

\subsection{Hasil}

Hasil penelitian yang ditunjukan melalui insrumen tes dalam pembelajaran matematika ditunjukan pada Tabel 2.

Tabel 2. Presentase Hasil Penelitian

\begin{tabular}{ccccccccc}
\hline & Banyak & Jumlah & Skor & Skor & & & & \\
Indikator & Data & Skor & Max & Min & Mean & Median & Modus & Presentase \\
\hline Pemahaman & 21 & 75 & 5 & 1 & 3,57 & 4 & 5 & 71 \\
Penerapan & 21 & 75 & 5 & 1 & 3,57 & 4 & 5 & 71 \\
Analisis & 21 & 757 & 47 & 17 & 36 & 37 & 35 & 70 \\
Sintesis & 21 & 797 & 50 & 17 & 37 & 39 & 34 & 70 \\
Evaluasi & 21 & 456 & 32 & 6 & 21 & 21 & 20 & 67 \\
\hline
\end{tabular}

Pada Tabel 2 ditunjukkan hasil belajar matematika pada indikator pemahaman mendapatkan kategori kurang dengan resentase $71 \%$, pada indikator penerapan mendaptkan kategori kurang dengan presentase $71 \%$, pada indikator analisis mendaptkan kategori kurang dengan presentase 
$70 \%$, pada indikator sintesis mendapatkan kategori kurang dengan presentase $70 \%$ dan pada indikator evaluasi mendapatkan kateori kurang dengan presentase $67 \%$.

\subsection{Pembahasan}

Indikator pemahaman siswa diharapkan mampu memahami materi-materi tertentu yang sudah dipelajari. Seperti kemampuan dalam memahami sebuah fakta, konsep, dan prinsip. Berdasarkan temuan dilapangan, hasil belajar siswa pada indikator ini dapat katakan kurang atau rendah. Hal ini dilihat dari kemampuan siswa dalam menyelesaikan soal yang diberikan, sebagian besar siswa tidak dapat mengerjakan soal dengan baik dan tepat.

Indikator penerapan diartikan sebagai kemampuan siswa dalam menerapkan informasi pada situasi yang kongkrit, dimana siswa mampu menerapkan pemahamannya secara nyata. Dari indikator pemahaman dan penerapan sebagian siswa belum memperoleh nilai yang maksimal. Hal ini dilihat dari kemampuan siswa dalam menyelesaikan soal yang diberikan, sebagian besar siswa tidak dapat mengerjakan soal dengan baik dan tepat.

Indikator analisis yaitu kemampuan menguraikan suatu informasi terhadap suatu materi menjadi komponen-komponen yang lebih jelas. hasil belajar siswa pada indikator ini dapat katakan kurang atau rendah. Hal ini dilihat dari kemampuan siswa dalam menyelesaikan soal yang diberikan, sebagian besar siswa tidak dapat mengerjakan soal secara bertahap dan masi banyak siswa yang belum bisa mengerjakan soal dengan baik dan tepat.

Indikator sintesis merupakan kemampuan berpikir yang merupakan kebalikan dari proses berpikir analisis siswa. Berdasarkan temuan dilapangan, hasil belajar siswa pada indikator ini dapat katakan kurang atau rendah. Hal ini dilihat dari kemampuan siswa dalam menyelesaikan soal yang diberikan, sebagian besar siswa tidak dapat mengerjakan soal secara bertahap dan masi banyak siswa yang belum bisa mengerjakan soal dengan baik dan tepat.

Indikator evaluasi merupakan kemampuan siswa dalam mengevaluasi soal yang diberikan. Indikator ini seperti kesimpulan. Berdasarkan temuan dilapangan, hasil belajar siswa pada indikator ini dapat katakan kurang atau rendah. Hal ini dilihat dari kemampuan siswa dalam menyelesaikan soal yang diberikan, sebagian besar siswa belum dapat menyimpulakan atau pernyataan yang benar pada soal yang diberikan.

\section{Kesimpulan}

Hasil belajar matematika siswa melalui pembelajaran berbasis e-learning di kelas XI TKJ'A SMK Negeri 2 Limboto tergolong pada kategori kurang dengan hasil presentase 69\%. Hasil belajar matematika siswa pada materi matriks digolongkan 4 kategori yaitu 12 orang berada pada kategori kurang dengan prsentase $57,10 \%, 3$ orang siswa berada pada kategori cukup dengan prsentase $14,30 \%, 5$ orang siswa berada pada kategori baik dengan presentase $23,80 \%$ dan 1 orang siswa berada paa kategori sanga baik dengan presentase $4,80 \%$.

\section{Referensi}

[1] W. Wiryanto," Proses Pembelajaran Matematika di Sekolah Dasar di Tengah Pandemi Covid-19," Jurnal Review Pendidikan Dasar: Jurnal Kajian Pendidikan dan Hasil Penelitian., Vol.6, No.2, 2020

[2] A. Sadikin dan A. Hamidah," Pembelajaran Daring di Tengah Wabah Covid-19," Jurnal Ilmia Pendidikan., Vol. 6, No. 2, pp 214-224, 2020

[3] U. Verawardina, L. Asnur, and A. L. Lubis," Review Online Learning Facing The Covid-19 Outbreak," Talent Development and Excellence., Vol. 12, No. 3s

[4] L. D. Herliandry, N. Nurhasanah, M. E. Suban, and H. Kuswanto," Pembelajaran Pada Masa 
Pandemic Covid-19," Jurnal Teknologi Pendidikan., Vol. 2, No. 1, pp 65-70, 2020

[5] M. Rahmatia, M. Monawati, and S. Damius," Pengaruh Media E-learning Terhadap Hasil Belajar Matematika Siswa,"Jurnal Ilmu Pendidikan Guru Sekolah Dasar., Vol. 2, No.1, pp. 212-227, 2020

[6] D. N. Suliswati," Efektivitas Pembelajaran Matematika Menggunakan Media Berbasis Elearning," Jurnal Pendidikan Matematika ., Vol. 2, No. 1, pp 58-65, 2019

[7] M. Nakayama, H. Yamonto, and R. Santiago," The Impact Of Learner Characteristics On Learning Performance In Hybrid Courses Among Japanese Students," The Electronic Journal Of E-learning., Vol. 5, No. 3, pp 195-206, 2007

[8] D. Wunggli, and L. Yahya," Pengaruh Penggunaan Media Berbasis Information and Comunication Technology (ICT) Terhadap Hasil Belajar Siswa Pada Materi Dimensi Tiga" Jambura J. Math. Educ., Vol. 1, No. 1, pp.41-47, 2020

[9] S. D. Tamu, E. Hulukati, and I. Djakaria, "Pengembangan Modul dan Video Pembelajaran Matematika Persiapan Ujian Nasional pada Materi Dimensi Tiga," Jambura J. Math. Educ., Vol. 1, No. 1, pp. 21-31, 2020

[10] N.S. Hanun," Keefektifan E-learning Sebagai Media Pembelajaran Studi Evaluasi Model Pembelajaran E-learning ," Jurnal Pendidikan Vokasi, Vol. 3, No. 1, pp. 90-102, 2013

[11] M.F. Annur and H. Hermansyah, "Analisis Kesulitan Mahasiswa Pendidikan Matematika Dalam Pembelajaran Daring Pada Masa Pandemi Covid-19," Paedagoria J. Kajian, Penelitian dan Pengembangan Pendidikan., Vol. 11, No. 2, pp. 195-201, 2020

[12] L. Lutfiyah, and D.N. Sulisawati, "Efektifitas Pembelajaran Matematika Menggunakan ELearning," J. Pendidikan Matematika., vol. 2, no. 1, pp. 58-65, 2019

[13] S.D. Handayani and A. Irawan, "Pembelajaran Matematika di Masa Pandemi Covid-19, “J. Math Educator Nusantara., pp. 181-189, 2020.

[14] Q. Ayun, D. A. Sujiwo, and A. W. Hidayatullah," Pengaruh E-learning Terhadap Hasil Belajar Matematika Pada Mahasiswa Teknik Informatika," Jurnal Sistem dam Teknologi Informasi Indonesia., Vol. 4, No. 1, pp 27-34, 2019.

[15] A. W. Abdullah, N. Achmad, and N. C. Fahrudin, "Deskripsi Hasil Belajar Matematika Siswa Melalui Pembelajaran Daring pada Pokok Bahasan Bangun Ruang Sisi Datar," Euler J. Ilm. Mat. Sains dan Teknol., vol. 8, no. 2, pp. 36-41, Dec. 2020, doi: 10.34312/euler.v8i2.10324. 